\title{
Research and Practice on the Model and Method of Funds Management in Colleges
}

\author{
Yuanyuan Tian \\ Zaozhuang University, Zaozhuang 277160, China \\ moralist@126.com
}

\begin{abstract}
Keywords: Funds management; Expense account; Capital efficiency; Optimization
\end{abstract}
\begin{abstract}
With the large-scaled extension of education and opening of market economy, the development of college and university is restricted by capital flow. How to strengthen the financial management and simplify the process of expense account, how to speed up the capital turnover rate and service efficiency, and how to make full use of the limited funds for sustainable development, are the key points for colleges and universities to keep on developing stably at present time. Taking a college financial work and expense account process as an example, we figure out the problems and disadvantages which are becoming increasingly apparent. Through a thorough analyses and discusses, the rationalization proposals and solutions on how to make full use of capital by optimizing the system regulations and processes are given in this paper.
\end{abstract}

\section{Introduction}

Under the environment of socialist market, the financial situation of colleges and universities encounters some difficulties with the rapid development of economy. With the unceasingly expanding in the recruitment of students' scale, fund investment from the government is increasing year by year [1,2]. While there still exist a big cash flow shortage in basic construction, teaching and scientific research, and other sustainable development of colleges and universities, especially the newly founded local undergraduate college. Competitive in the financial management of colleges and universities, especially the capital management, is the premise and guarantee for further development. It is related to future successfully and smoothly running in education, teaching, scientific research, infrastructure, logistics and a series of work inline.

Utilizing and managing of funds in colleges and universities usually contain the steps of capital budget in advance, check and control in the middle, and supervision and analysis at last [4,5]. In this paper, the author makes a thorough analysis of the highlighted problems by investigating the situation of fund usage in the university. By comparison with the mode and the method for fund management of foreign universities, the improvement plan for college fund management is put forward in this paper. Starting with the system construction for fund management mode and process control respectively, supported by networking computer and other modern office tools, a new financial management information system is established to optimize the expense reimbursement process, strengthen the management of various funds, and realize the maximization of the use of funds.

\section{Current Status of College Fund Management at Home and Abroad}

Current Status of College Fund Management Abroad. American colleges and universities belong to the federal government [6]. The government can make tax revenue as the government funding, and provide financial resources to colleges and universities by budgeting, social investment, which constitute important part of the college funding sources.

Since the 1980s, the governance system of colleges and universities has gradually adopted the board system, i.e. it's directed by the school board while the principal take full management responsibility. The board of American universities manage the affairs of the university by established standing committee. The executive committee and the financial planning commission shall be responsible for the detailed 
arrangements for the submission of the budget and the arrangement of funds, and periodically assess the use of funds and the external and external debt [7]. The fund management adopts the decentralization management mode, the board of directors shall formulate the annual and long-term capital management plan, and the university President shall be responsible for the implementation of the policy. This management model is an important guarantee for the booming development of education in western developed countries, such as the U.S. and Japan in the second half of the 20th century. The separation of decision and execution in a certain degree is beneficial to the board of directors, as they can formulate fund policies in the absence of external environmental factors such as school development [8]. So it is also beneficial to the long-term development planning of the school. And it is beneficial for all the subordinate college to actively, creatively, independently implement various of capital management policy in money management activities. In the process of capital policy implementation, it has greater freedom in running schools and autonomy of funds, which greatly improves the efficiency of capital management.

German universities are funded mainly by federal grants and corporate investment. State funding is mainly responsible for the management of cost, equipment investment, infrastructure spending half (the other half by the federal government subsidies), and so on. In addition, German university scientific research investment funds can also apply for additional funding from the central government [9]. Business investment accounts for about 40 percent of total school funding. As we can see, the German government has invested more money in education. With federal and state funding and subsidies, Germany's high education resources are sufficient to pay for general overhead expenses [10]. The funds collected from the "third party" enterprises, known as "the third type of funds", it's raised by teachers through their own research projects and signed a technology transfer or contract, and entirely free from the teachers themselves. In addition, colleges and universities accept both the government and the law of the state. But also have great flexibility of running schools, and certain autonomy for the university education resources.

Current Status of College Fund Management at Home. Money is in short supply. With the steadily increasing financial capital investment year by year, annual income is up to nearly 200 million, which mainly includes government allocated budget funds, tuition collection non-budgetary funds and house disposal income. While there still exist a big cash flow shortage in basic construction, teaching and scientific research, and other sustainable development of colleges and universities, especially the newly founded local undergraduate college. This can only rely on financing from financial institutions.

The fund adopts the combination of decentralized management and macro-control. At present, the allocation of financial funds in a university is mainly decentralized management and supplemented by overall management. Most of the funds are assigned to each secondary school and the department in charge of funds at the beginning of this budget funds according to the way in previous years. Only a few funds are left for the college's basic maintenance and development needs.

The duplicated examination and approval process, the complicated expense reimbursement process, and all the operation by hand, are all seriously affect the capital use efficiency. Although the so-called accounting computerization is realized in some university, it is essentially a closed system just for financial workers. Only parts of hand work are replaced by computer, like original handcrafted credentials, manual bookkeeping, manual check and review. It can't cover the whole part of expenses reimbursement process, such as reporting, budgeting, budgeting control, leadership approval, real-time reimbursement, etc. So a real-time financial software or network system is in deep need.

\section{Existing Problems of Funds Management in Zaozhuang University}

The capital source is single. The primarily source of capital funding is the fiscal appropriation from the government. The college itself cannot raise and attract foreign capital to maintain the daily work like teaching, scientific research, logistics, along with basic construction. Provided funding for career development is very limited due to the serious shortage of funds

The Fiscal Control is Decentralized. In the decentralized management mode of financial funds, most of the funds are allocated to the secondary colleges or departments charging of special funds, 
which result in relatively scattered financial control rights. It's difficult to concentrate capital on great things, or transfer the capital among surplus and deficit at any time, while easy to cause certain duplicative spending in some projects. In addition, it's prone to corruption if the departments of the secondary colleges or functional departments have too much rights on use of the special funds in department.

The Mode of Operation is Handwork. The appropriations process of the examination and approval system is heavy and complicated, characterized in the following disadvantages: Firstly, reimburse process of drawn up all kinds of documents are all by hand. It's a hard work and occupies faculty a large number of working hours for its large amount of information, heavy workload, and many examination and approval department involved. Secondly, a large number of scattered, improvised, repetitive work is cut in line at anytime and anywhere. It's a disruption of the normal daily work plan, also increased the time and cycle of expense reimbursement, which make capital turnover and use efficiency greatly reduced. Thirdly, the real-time control of the budget cannot be realized in the process of expense reimbursement. The administrative staff or financial personnel cannot know at real-time the budget process or the budget balance among each department, and can only control it after reimbursement, which blocks the rapid transfer of information and capital, and also easy to appear over budget.

\section{Reform and Practice of Funds Management in Zaozhuang University}

Overall Capital Control. First of all, using their own advantage in talent and scientific research, colleges and universities should increase joint with local enterprise, joint between colleges, attract more funds from transfer of the patent technology, paid services, investment of equipment, or other various forms of resource investment, to maximize funding sources for colleges and universities. Furthermore, allocate resources of university funds and other resources to a large finance, and the allocation of funds from the original departments and special allotment will be changed to a special allocation and reserved for certain mobile funds. The university establishes centralized management leadership mode in charge of the resources (especially funds), which is continent to use the limited funds for the basic, important projects and centralize power to do the big things. This method is extremely beneficial to the complementary surplus of funds, avoiding the duplication of expenditure of multiple departments and projects, and avoiding corruption.

Financial Management Control. Mainly includes the control of the budget management, examination and approval system of control and supervision of the head of department. Strictly according to the budget of the year with real-time control, the phenomena of beyond budgeting is not allowed to happen. Approval system should not only legal but also be simplified, science, and only in this way can reduce the waste on the examination and approval to a certain extent, and put more working time and energy on management decisions. More important, it can improve the service efficiency of funds. Divided the college capital into special funds allocation, such as scientific research, teaching, practice expenditure, laboratory funds, et al. Establish a strict audit supervision system focus on the running capital of departments in charge of the special funds.

Optimization of Expenses Reimbursement Process. Adding budget approval process before traditional reimbursement will, it's possibly strengthen the control of dispatching and surplus at different stages to a certain extent, but overall, has greatly increased the cost of reimbursement: Costs of faculty to fill out information tables with multiple layers, costs of in charge department or the head of it to examination and approval, cost of submission materials from various departments to the bursar's office, and so on. At the same time, it extended the time of reimbursement and reduced the efficiency of capital use. Therefore, the role of budget approval process is cancelled in our reformation to raise up efficiency and save cost.

Authoring of Software. In addition, the author designed a set of safe, practical and efficient financial management software, include the staff budget report, reimbursement documents fill up, examination and approval by various departments and supervisor, and other functions. It's an organic whole system based on existing campus network platform, which can announce and share the accounting information, 
to satisfy different users of the financial activities like expenses reimbursement, budget control, receivable management, information query, supervision, etc.

\section{Summary}

Through the analysis of the status quo and operation mode of expenses fund management in some at home and abroad colleges, comparing foreign universities fund management mode, the reform of system and process optimization of Zaozhuang University is discussed in this article.

The problems and methods discussed in this pare is not only a case-by-case example. It's a common case sustainable for the similar colleges and universities with the same scale, especially the newly founded local undergraduate colleges.

\section{Acknowledgements}

This work is supported by Shandong provincial natural science foundation (No. ZR201702200400); Science and technology program of Shandong higher education institutions (No. J17KA087); The program of independent innovation and achievement transformation plan for Zaozhuang (No. 2016GH19); Science and technology program of Zaozhuang (No. 2016GX31); The educational reform key projects of Zaozhuang University.

\section{References}

[1] Y.Y.Tian: International conference on ICESAME (Zhengzhou, China, April 29-30, 2017), Vol.123, P378.

[2] C.G.Zhang: University Logistrics Research, (2013)No3, P61 (In Chinese).

[3] H.W.Wang:CFO Comments, (2017)No3, P50 (In Chinese).

[4] S.S.Yu: Economist, (2017)No6, P198 (In Chinese).

[5] Y.Liang, S.D.Gan: J. Sichuan Normal University (Social Sciences Edution), Vol.41 (2017)No2, P79 (In Chinese).

[6] Y.F.Jiang, Y.F.Wu, B.Wang: J.Nanjing Institute of Industry Tehnology, (2017)No.1, P31 (In Chinese).

[7] S. Y.Chyung, A. J. Moll, S. A.Berg: The Journal of EffectiveTeaching, Vol.10 (2010)No.1, P22.

[8] T.Mavruk, E.Carlsson: Social Science Electronic Publishing, Vol.5(2015)No.1,P33.

[9] M.N.Maureen, T.Brett: Journal of Accounting \& Economics, Vol.17(1994), No1,P69.

[10] J.A.Milian: Review of Quantitative Finance \& Accounting, Vol.47(20145),P20. 